\title{
DiE VROU WySHEID, GOD, EN EKOBILLIKHEID: LIGGAAMSIDEOLOGIE IN SPREUKE 8:1-9:18
}

Author:

Philip P. Venter ${ }^{1}$

\section{Affiliation:}

${ }^{1}$ Departement

Ou-Testamentiese

Wetenskap, Universiteit van

Pretoria, Suid-Afrika

\section{Correspondence to:}

Dirk J. Human

e-mail:

dirk.human@up.ac.za

\section{Postal address:}

Departement Ou-

Testamentiese Wetenskap,

Fakulteit Teologie,

Universiteit van Pretoria,

Lynnwoodweg, Hatfield

0083, Suid-Afrika

\section{Keywords:}

Spreuke; Godskonstrukte; kosmologiese terminologie; skeppingswerke; genderpolarisasie

\section{Dates:}

Received: 4 Mei 2009

Accepted: 11 Junie 2009

Published: 05 Nov. 2009

How to cite this article: Venter, Philip P., 'Die vrou Wysheid, God, en ekobillikheid:

Liggaamsideologie in Spreuke 8:1-9:18', HTS Teologiese Studies/Theological Studies 65(1), Art. \#306, 7 pages. DOI: $10.4102 /$ hts. v65i1.306

\section{This article is available} at:

http://www.hts.org.za

\section{Nota:}

Philip P. Venter is ' $n$ navorsingsgenoot van prof. dr D.J. Human in die

Departement OuTestamentiese Wetenskap,

Fakulteit Teologie, Universiteit van Pretoria.

(c) 2009. The Authors. Licensee: OpenJournals Publishing. This work is licensed under the Creative Commons Attribution License.

\section{ABSTRACT}

The woman Wisdom, God, and ecojustice: Ideology of the body in Proverbs 8:1-9:18

This article examines the ideology of the body, specifically in terms of the gender of Wisdom and God, from an ecojustice perspective. Femininity within a God construct could contribute to a value system that incorporates compassion, interrelatedness and mutual care. In Proverbs 8:1-9:18, however, the woman Wisdom does not represent an ecofriendly construct, but simply enhances and supports the patriarchal, masculine values incorporated in the God Yahweh.

\section{INLEIDING}

Die metaforiese krag van die vroulike verpersoonliking van Wysheid in Spreuke 8:1-9:18, en die noue verband waarin hierdie vrou met Jahwe staan, hou bepaalde moontlikhede vir ekobillikheid in. Godskonstrukte waarin ook vroulikheid opgeneem is, kan tot ' $n$ meer gebalanseerde ideologiese siening van die mens se verhouding met die Aarde en haar bewoners bydra, aangesien dit die 'heers en beheers'-ideologie dekonstrueer, en aspekte soos deernis en onderlinge sorg en verbondenheid impliseer. Wat is dieliggaamsideologie, bepaald wat gender betref, onderliggend aan die personifikasies in voormelde Skrifgedeelte, en watter bydrae lewer dit tot ekobillikheid?

\section{BELIGGAAMDE PERSONIFIKASIES VAN GOD EN WYSHEID} Voor die hand liggende liggaamlikheid

In Spreuke 8:1-9:18 word daar geen liggaamlike eienskappe aan God toegeken nie, met uitsondering van dit wat in die verlede, met die skepping, gegeld het. In die hede is God bloot self een wat passief/ nieregstreeks guns betoon aan dié wat Hom dien. Daarenteen is die vrou Wysheid daadwerklik aktief/besig. Kenmerkend van haar aktiwiteit is die gebruik van spraak. Tog is die personifikasies van die vrou Wysheid en Jahwe in ' $n$ mate verweef en veelduidig, en is die skeidslyn tussen die twee soms vaag, soos uit die volgende gedeeltes blyk:

- In Spreuke 8:13 beskryf die vrou Wysheid haar as iemand wat die Here dien, en wat haat wat verkeerd is

- In Spreuke 8:22 is die vrou Wysheid die eerste een wat deur die Here geskep is

- In Spreuke 8:24-29 is die vrou Wysheid 'n ooggetuie van God se skeppingsproses

- Sy verskaf vreugde aan die Skepper, en geniet sy teenwoordigheid in Spreuke 8:30

- In Spreuke 8:31 verlustig die vrou Wysheid haar in God se skepping en skepsele

- In Spreuke 8:35 verskaf sy die lewe self, met dié kwalifikasie dat die guns van die Here daaroor regeer

- In Spreuke 9:10 word sy as onlosmaaklik verbonde aan (die eienskappe van) Jahwe beskryf.

Die uitdrukking in Spreuke 9:10 is die spil waarom die vrou Wysheid se rol as bemiddelaar, bemagtiger en opvoeder draai. Wysheid het nie net by Jahwe begin nie; Wysheid is ook die begin van 'n verhouding met Jahwe. Trouens, die onderskeid tussen Jahwe en die vrou Wysheid verdwyn heeltemal met die parallelisme in Spreuke 9:10. Daar is geen twyfel dat dit hier oor Jahwe as God gaan nie. Die liggaamsideologie onderliggend aan die Jahwe van Spreuke 8 en 9 kan egter uit die vrou Wysheid se rol afgelei word. Kon Wysheid dus ontkom aan die heersende Israelitiese liggaamsideologie van manlikheid, en is sy ' $n$ (navolgenswaardige) persoon uit eie reg?

\section{Die vrou Wysheid in die openbare sfeer}

Die openbare sfeer is 'n manswêreld; die huishoudelike behoort aan die vrou (Viviers 2005:882). Daarom verhoog die beskrywing van die vrou Wysheid se teenwoordigheid in openbare plekke onmiddellik die impak van haar retoriek. Die vier plekaanduidings in Spreuke 8:1-3 is die setels van kommersiële aktiwiteit, regspleging en die sosiale lewe. Hier is moontlik 'n groot gehoor vir die vrou Wysheid se woorde, in teenstelling met Spreuke 9:1-5, waar sy in die privaatheid van haar huis optree.

Fox (2000:265) wys op die skerp en duidelike kontras met voorafgaande hoofstuk 7, waar 'die vreemde vrou' (Bybel 1953-vertaling) haar in 'n gedempte stemtoon op die donker straathoeke en stadspleine aan die jongmanne beskikbaar stel. Die vrou Wysheid verkondig haar boodskap hard en duidelik op die mees openbare plekke in en om die stad. Haar openbare verskyning is nie ' $n$ alleenstaande voorval nie, maar 'n voortdurende, tipiese optrede. Dié beskrywing verkry 'n atemporele karakter - die vrou Wysheid spreek immers 'alle manne' (Bybel 1953-vertaling) in alle stede aan, binne én buite die stadsmure, op hoë plekke én waar die aksie en beweging is. Sy het die drumpel na die openbare sfeer oorgesteek. Dáár beweeg sy selfversekerd en heel openlik. Dit is veelseggend dat die vrou Wysheid die mans van die stad aanspreek en na hulle roep. Die voorwerp van haar optrede, die mans, word in die 1983-vertaling as 'alle mense' bestempel. As sy dus deur haar optrede tot die morele heil en samehang van die gemeenskap wil bydra, het dit weens die plek waar sy haar bevind sowel as haar fokus, met manlikheid te make, net soos wat die openbare optrede van die vrou Dwaasheid in die laaste gedeelte van Spreuke 9, óók in daardie openbare, manlike sfeer, 'n genderbepaalde motief het. Dit gaan daaroor om die harte van die mans, die kultuurdraers van die destydse samelewing, te verower. 
Voorts betree die vrou Wysheid die manlike sfeer deur die aard van haar optrede. Sy roep, laat haar stem hoor, en skree haar boodskap uit. Spraak of bevel, om dus orator te wees, is 'n kenmerk van manlikheid. Dit dui op sofistikasie; die soort wêreldwysheid wat eie is aan mans. Die vrou Wysheid toon ook ' $n$ begeerte om te skep, te herskep en te beheer. Die dinge wat vroue kwytraak is destyds gewoonlik as ydele praatjies bestempel (Eilberg-Schwartz 1995a:6). In Spreuke 8:1-3 word dit kategories gestel dat Wysheid hier in die persoon van ' $n$ vrou aan die woord is. Sy is egter nie die dwase vrou wat onoordeelkundige uitlatings maak, so asof haar mond met haar vagina geassosieer word en dit onvermydelik losbandigheid, gevaar en afgodery tot gevolg het nie (Eilberg-Schwartz 1995b:174), maar sy het klaarblyklik 'n positiewe, skeppende of herskeppende motief. Sy word immers Wysheid genoem. Nie alleen blyk haar navolging van manlikheid en die patriargie, soos Viviers (2005:888) wel aantoon, uit die 'produkte' van haar mond nie, maar bevraagteken die blote feit dat sy as orator optree ook die ware vroulikheid van Wysheid. Van stilwees wat betref lydelikheid, verduring, passiewe aanvaarding of onderworpenheid, soos wat in die patriargale samelewing van vroue verwag is, is hier ook geen sprake nie.

\section{Haar aanbod is suiwer en seker}

Die vrou Wysheid bemagtig jong, weerlose en onervare mans van die gemeenskap in twee opsigte: Sy bied haar en haar eienskappe aan om in besit geneem te word, en sy skenk sekere gawes of vermoëns aan diegene wat met haar omgaan.

Die eienskappe van die vrou Wysheid lê in die integriteit van haar woorde, naamlik voortreflikheid, opregtheid, waarheid, afsku aan wat verkeerd is, beproefdheid, goeie bedoeling, direktheid en moraliteit. Haar woorde is meer werd as silwer en fyn goud. Wat ooglopend kortkom, is eienskappe soos deernis, besorgdheid en genade. Malul (2002:106) gee 'n raak beskrywing van die gebruik van gesuiwerde silwer en goud as metafore vir die waarde van die vrou Wysheid se woorde as hy daarop wys dat die metafoor op die verwydering van onsuiwerheid of onsuiwerhede (die droes) dui. Enige toeval en veelkansigheid met betrekking tot die gender-ideologie onderliggend aan die vrou Wysheid se woorde word dus uitgeskakel deur haar woorde met eienskappe te beskryf wat tot die hoër menslike funksies behoort, met ander woorde die wêreld van die denke, eerder as die wêreld van die liggaam.

Dieselfde geld die gawes of vermoëns wat die vrou Wysheid bied: verstand, kennis, insig en goeie raad, wat alles tot sukses lei. Nogeens is die 'liggaam' van wat die vrou Wysheid die jongmanne bied op 'n gesuiwerde liggaam gemodelleer - 'n beheerste liggaam waarin die verborgenheid en bedreiging van die onderste liggaamsdele, dit waarmee vroulikheid geassosieer word, nié voorkom nie. Die gawes of eienskappe wat sy die jongmanne bied, kom van binne die liggaam, vanuit die 'hart' as sentrum van bewussyn. Dit is dus konkrete, liggaamlik bepaalde entiteite. In die antieke epistemiese proses was kennisverwerwing nie ' $\mathrm{n}$ abstrakte, filosofiese proses nie, maar ' $n$ liggaamlike interaksie. Kognitiewe prosesse is konkreet en sintuiglik beskou. So beskryf Fox (2000:268) die Hebreeuse woord bl en Spreuke 8:5 as 'the organ of cognition and memory as well as the locus of emotion'. Die hart ís deel van die liggaam, maar wel van die manlik vooropgestelde gedeelte van die liggaam. Daarom is dit veelseggend as die wisselwerking tussen die vrou Wysheid en die mans eienskappe soos skranderheid, die vermoë om tussen reg en verkeerd te onderskei, insig en regsinnigheid tot gevolg het.

\section{Mag en die vrou Wysheid loop saam}

Die uitdrukking twon('skranderheid') in Spreuke 8:12 word naas 'verstand' en 'kennis' gestel, en word as eienskappe van wysheid beskou. Malul (2002:149) wys op die verband met die konsepte 'raad', 'sukses', 'insig', en baie veelseggend, met 'mag' wat later in die gedeelte voorkom. Hy beklemtoon dat 'mag' en 'wysheid' dikwels parallel of in noue verband met mekaar gebruik word, soos in Jeremia 9:22, Job 12:13, Prediker 9:16 en Daniël 2:20, en ook hier in Spreuke 8:14, want wie die vrou Wysheid het, het ook mag. Om 'skranderheid' (t in so 'n noue verband met 'mag' (hr) te gebruik, en dit boonop met wysheid te verbind, weerspieël die wisselwerking tussen die semantiese velde van kennis en beheer.

In Spreuke 8:14-21 word die bemagtigende uitwerking van Wysheid, wat die eienskappe van skranderheid, verstandigheid, insig, ensovoorts toon, uitdruklik gestel: Sukses volg. As daar twyfel bestaan oor watter soort sukses bedoel word, word dit duidelik uit die beskrywing van die konings wat goed regeer (Spr 8:15) en die maghebbers wat doeltreffend heers (Spr 8:16) wat rykdom en eer verkry (Spr 8:18); die wyses kom in besit van duursame en blywende dinge (Spr 8:18); hulle word ryk, en hulle skure word vol (Spr 8:21). Jahwe, die beliggaming van manlikheid, toon veral hierdie beeld. Skranderheid in die uitvoering van beleidmaking of regeringsmag is ' $n$ aktiwiteit wat aan mans toegedig word, so ook die ander goeie eienskappe wat hier vermeld word. Vorster (2002:36) wys op die belang van selfbeheersing, insig, geregtigheid en moed as noodsaaklike voorvereistes vir ' $n$ liggaam om doeltreffend in ' $n$ leiersrol in die gemeenskap te funksioneer. Indien die vrou Wysheid se hulp volgens Spreuke 8:15 dus daartoe lei dat konings goed regeer en maghebbers reg ( $q d x$ ) laat geskied, is dit tog duidelik dat die manlike reguleringsliggaam by die jongmanne ingeprent word vir wie die vrou Wysheid bemagtig. Hierdie 'liggaam' beskik oor selfbeheersing en onderskeidingsvermoë, en speel 'n beskermende, regulerende rol in die destydse sosiale bestel. Dít is wat die vrou Wysheid verteenwoordig en bied. Sy bemagtig die mans van haar samelewing, en word ' $n$ agent vir en voorstander van die dominante manlike kultuur (Viviers 2005:883).

\section{Wie die vrou Wysheid het, ontvang geskenke}

Spreuke 8:17-21 word gekenmerk deur die raamwerk van liefde waarin dit gegiet is. Die vrou Wysheid self erken die wederkerige aard van die liefde tussen haar en diegene wat haar liefhet (Murphy 1998b:51). Dié gedeelte toon tekens van die (soms erotiese) taal wat elders, onder andere in Spreuke 4:5-9, vir die najaag van die vrou Wysheid gebruik word. Dáár val die klem egter op die méns se liefde vir Wysheid. In Spreuke 8:17 is liefde een van die belonings uit háár hand; háár geskenk wat sy bied aan dié wat haar soek. Die aard van daardie liefde word egter in ' $\mathrm{n}$ mate deur die uitwerking daarvan omskryf. Dit bring gawes mee wat die man in sy sosiale omgang goed te pas sou kom, naamlik rykdom, eer, duursame en blywende besittings, dinge wat selfs waardevoller is as fyn goud en suiwer silwer (kyk Malul se vertolking van dié metafoor vroeër in die artikel). Daarbenewens word die pad van die vrou Wysheid en diegene wat haar vind as ' $n$ pad van geregtigheid en reg beskryf. Dit wek die indruk dat wat ' $n$ mens ook al vir ' $n$ kommervrye, gebalanseerde bestaan nodig het, die man wat Wysheid vind genoeg van sal hê. Die man word dus bemagtig om die samelewing se waardes, styl en gebruike te help bewaar omdat hy oor die nodige middele en gawes, sowel innerlik as uiterlik, beskik om dit te kan doen.

Voorts hou die internalisering van wat die vrou Wysheid bied die belofte van haar eie heelheid of balans in. Sy bring die volmaakte wysheid uit haar binneste te voorskyn, wat impliseer dat sy self heel, in beheer en gebalanseerd is, soos die ideale manlike liggaam. Om haar 'in besit te neem' is om soos sy self, of eerder hy self, te word: die ideale of perfekte maatstaf vir 'n goed geordende samelewing (Viviers 2005:883). Vroue het nie hierdie soort balans en beheer nie, omdat hulle volgens die genderhiërargie in antieke denke eenvoudig oor minder daarvan beskik - dus is hulle eerder voorwerpe van beheer.

\section{Die vrou Wysheid se kosmiese oorsprong}

In die beskrywing van die vrou Wysheid se kosmiese oorsprong in Spreuke 8:22-31 tree Jahwe as Skeppergod op die voorgrond. God word beskryf as iemand wat maak, wat skep, en dus handelend en aktief by die skepping betrokke is. 
Hy orden, en werk soos ' $n$ argitek en bouer. Die (gevaarlike, chaotiese, vroulike) see word ingeperk en onder die bevel van God gestel. Die konstruk van 'n Skeppergod voldoen aan die ideale liggaamsbeeld van die Israelitiese liggaamsideologie. Sy liggaam is manlik, perfek beheers en in balans, en só vorm hy die makrokosmos, naamlik die skepping.

McKinlay (1996:75) beklemtoon dat, in teenstelling met Spreuke 8:12 waarin Wysheid se verstand en skranderheid geprys word, Jahwe verantwoordelik is vir alles wat kosmologies beskryf word. Alles begin met Jahwe. Daar is geen sprake van ' $n$ outonome Wysheid nie. Is dít ' $n$ aanduiding dat die vrou Wysheid eintlik maar ' $n$ 'kloon' is van Jahwe, wat haar gesag, eer en status bekragtig en onderskryf (Viviers 2005:884)?

Haar kosmiese oorsprong, nog voor die begin van tyd, blyk duidelik uit die beskrywing in Spreuke 8:22-29. Op ' $n$ manier word sy met die ewige Jahwe vereenselwig, en daarom is die vrou Wysheid se roepstem ook Jahwe se roepstem. Sy is, volgens Murphy (1998a:40-41), die openbaring van God, en nie bloot die selfopenbaring van die skepping nie. Sy is die goddelike roepstem wat in en deur die skepping uitgevaardig word, en haar stem weerklink in elke sfeer van die geskape wêreld, en dring selfs die menslike bewussyn binne.

Presies hóé veelduidig die ontstaan van die vrou Wysheid in 'n kosmiese sin egter is, blyk uit Pentiuc (2001:255-265) se vertolking van die skepping van Wysheid as 'n selfopofferende daad van God: 'She was poured out as a libation.' Sy is 'berei' (Spr 8:22, 1953-vertaling) en 'gebore' met geboortepyne (Spr 8:24). Daarom is Wysheid ewig saam met God. Sy word nie, soos in die geval van die see, bloot toegelaat om as deel van God se skepping te bestaan nie, maar word spesiaal berei, verkry en gebore deur die Skepper om sy gelyke metgesel of vertroueling te wees.

Voorstanders van die teorie dat Wysheid die hipostase van Jahwe is, beskou die vrou Wysheid as die verlenging of versterking van een van die eienskappe van die 'Hoë God'. Vir Fontaine (2002:95) is dit asof die wysheid van God, 'n verskynsel in latere Bybelse tekste, 'n lewe van sy eie kry. God se wysheid verteenwoordig ' $n$ aspek van sy alwetendheid, en die vermoë om te reproduseer, en word in die vrou Wysheid beliggaam. Fontaine (2002:95) meen dat só ' $n$ siening van Wysheid as hipostase van die Godheid by implikasie, suiwer op grond van die oorsprong van die karakter, 'n vroulike karakter as manlik weergee, sonder om in die eerste plek reg te laat geskied aan die voorstelling van Wysheid as 'n vrou.

Al sou ' $\mathrm{n}$ mens met Fontaine kon verskil, aangesien Spreuke 8:22-31 ' $n$ duidelike vroulike metaforisering van die Skeppergod bevat wat aan die vrou Wysheid geboorte skenk, staan daardie metafoor steeds te midde van die doelbewuste veelduidigheid van die beskrywing van Wysheid se oorsprong. Baumann (1998:60) beskou Spreuke 8:22-31 as 'n pasgemaakte voorstelling wat die implisiete voorveronderstellings van wysheidsteologie in ' $n$ soort metaforiese teologie weergee. Spreuke 8:22-31 toon met behulp van ' $n$ metafoor dat Jahwe ' $n$ goeie en wyse orde aan die wêreld gegee het. Hiervan is Wysheid, as ' $n$ voorbestaanswese en getuie van die oerskepping, ' $n$ waarborg. Dus is Wysheid in hierdie tekste ' $\mathrm{n}$ metafoor vir iets wat vantevore bloot in beredenerings of teorieë beskryf kon word.

Daar bestaan min twyfel dat die doel van die skepping (of geboorte) van Wysheid, en haar gevolglike optrede, 'n oproep is om die aanvaarding van en geloof in die goeie orde wat Jahwe, reeds voordat tyd begin het, by die skepping ingeweef het. As gevolg van haar kennis van die wêreldorde, kan die vrou Wysheid ' $n$ etos oordra wat Jahwe se wil en bedoelinge naboots: 'Her call is for a spiritual relationship of individuals towards her, which manifests itself by keeping the Torah' (Baumann 1998:71).

Die verhouding tussen Jahwe en die vrou Wysheid illustreer die beginsel van 'wederkerige deelwording' (Leder 1990) wat
Wysheid se kosmiese oorsprong betref. Om deur die oë van ' $n$ vrou na die skepping te kyk, is om dit vroulik te ervaar, vandaar die metafoor van geboorteskenking. Voorts vind daar wedersydse verlustiging tussen Jahwe en Wysheid plaas - speels en ter illustrasie van ' $n$ vertrouensverhouding. Minstens in haar kosmiese oorsprong verteenwoordig die vrou Wysheid ' $n$ aspek van die Godheid wat ruimte vir wedersydse waardering bied. Die vrou Wysheid het egter ' $n$ eie roeping, naamlik om die mans van Israel na Jahwe te bring.

Dit is juis op hierdie punt, die retoriek van die karakter Wysheid, dat dit blyk dat die noue verbintenis met Jahwe in genderterme gedekonstrueer word as Wysheid haar as die regte pad, die regte insig, die regte denke en lewenswyse aan die jongmanne bied. So ondenkbaar soos dit vir die mans van Israel was om aan God as vroulike moederfiguur te dink wat geboorte skenk, met die gepaardgaande bloedstorting, onreinheid en gedwonge afsondering, so ondenkbaar was dit om die vrou Wysheid as 'nuwe' godinfiguur, 'n nuwe God, te sien. Viviers (2005:884) stel dit só: '...[s]he inhabits the ultimate male regulatory body $(=Y a h w e h)^{\prime}$. In die wederkerige deelwording van die karakters van die skeppende Jahwe en die teenwoordige, verlustigende vrou Wysheid word dit duidelik wie Wysheid eintlik is, met wie sy verbind moet word, en wie sy verteenwoordig. Sy is nie ' $n$ vrou (subjek) uit eie reg nie. Om jou aan haar te onderwerp en haar te aanvaar, is om Jahwe se gesag te erken, en dít impliseer onderwerping aan die patriargale orde.

Al staan die beeld van Jahwe wat aan Wysheid geboorte skenk baie duidelik, onderskryf die vrou Wysheid die waardes van die manlike reguleringsliggaam, soos gesag, beheer, onderwerping en oorheersing. Daar is geen waarlik vroulike ervaring uit die metaforisering van Jahwe se skepping van die aarde en Wysheid af te lei nie - daarvoor is die geboortemetafoor te verskuil. Die vrou Wysheid, in haar oorsprong en getuienis van die skepping self, laat ook nie veel van ware vroulikheid en subjektiwiteit blyk nie. Sy ís vroulik, maar bloot 'n vroulike sy van 'n goddelike mag wat as oorwegend manlik beskou en beleef is (McKinlay 1996:80).

\section{Wysheid $=$ lewe $=$ die guns van die Here}

Die vermaning of raad in Spreuke 8:32-36 bied 'n aantal fasette wat belangrik is vir ' $n$ vertolking van die vrou Wysheid se rol en karakter. Eerstens skep die retoriek die indruk van ' $n$ wyse raadgewer, soos ' $n$ moeder vir haar seuns - dalk na analogie van die omvattende rol wat moeders destyds in die tipiese familie gespeel het (Fontaine 2002:27). Beleef teen die agtergrond van die herinneringe aan vervloë godinfigure, beskryf in ' $n$ didaktiese rol teenoor die seuns, en bemagtig deur haar teenwoordigheid gedurende die skepping, tree die vrou Wysheid nou in as belowende dog waarskuwende stem. Die vraag is of sy in ' $n$ nuwe era nuwe moederlike insigte en wysheid bied, en of sy bloot ' $n$ terugkeer na die ou tradisie bepleit. In die huislike lewe, maar nie in die gemeenskap se sosiale lewe nie, was die moeder se rol belangrik en gesaghebbend. Verskyn die vrou Wysheid dus hier in die rol van die sorgsame moeder, en indien wél, wie se waardes probeer sy by die seuns vestig? Ding sy dalk eerder hier as vrou, en nie as moeder nie, met ' $n$ ander verleidelike vrou mee wat haar seuns bedreig?

Die onderliggende tweeledigheid in haar raad is ooglopend en treffend. Aan die positiewe kant word voorspoed, wysheid, die lewe self, en die guns van Jahwe in ' $n$ kontinuum as beloning vir lojaliteit aan Wysheid gebied. Daarteenoor staan die negatiewe van skade en die dood. Dit is opmerklik dat die dood nie bloot deur afwysing of verloëning van Wysheid veroorsaak word nie. Dit gaan hier eerder oor ' $n$ bepalende keuse tussen persona. Wie nie vir Wysheid kies, in ' $n$ liefdesverhouding met haar verkeer, en haar gereeld opsoek om hierdie liefdesverhouding uit te leef nie, kies en besluit ten gunste van die vreemde of dwase vrou. Malul (2002:454) wys op die ruimtelike nuanse in die uitdrukking 'my nie wil vind nie' in Spreuke 8:36. Dit dui op 'n uittrede uit, of 'n wegbeweeg van, aanvaarde gedragslyne. As die seuns die vrou Wysheid kies, is hulle 'binne' die aanvaarde gedragskring. 
Om téén haar te kies, is om 'buite' die aanvaarde kring te staan. Die verband met die randfigure van die patriargale samelewing, veral vroue, is ooglopend.

Hierdie ingeboude tweeledigheid is belangrik vir die blootlegging van die liggaamsideologie agter die vrou Wysheid se optrede. Sy bied haarself as verteenwoordiger van die tipies manlike waardes van wysheid, voorspoed, kennis en insig aan. In Spreuke 8:35 word alles wat sy verteenwoordig in die uitdrukking 'die lewe self' saamgevat. Hiermee word die tweeledigheid dus nóg duideliker. Om manlike waardes na te jaag, is om te lewe. Om die waardes eie aan manlikheid van die hand te wys, is om jou eie graf te grawe.

Om alles te kroon, word die vrou Wysheid, die lewe, en die guns van Jahwe in Spreuke 8:35 in een asem as verweefde eenhede vermeld. Die enigste positiewe, bemagtigende of hoopvolle wisselwerking is dié tussen Jahwe, Wysheid, en die jongmanne van Israel. Dít omskryf die lewe. Die lewe is dus om alles wat Jahwe verteenwoordig, en wat die vrou Wysheid beliggaam, te 'vind'. Die vrou Wysheid voeg nie 'n nuwe sy tot die lewe in Israel toe nie. As ' $\mathrm{n}$ 'produk' wat volledig vanuit Jahwe kom, definieer sy die lewe as getrouheid aan die Jahwe-orde. Die vrou Wysheid is nie 'n rolmodel vir die lewe in die volle sin van die woord nie. Sy is bloot die noodsaaklik vroulik gemetaforiseerde teenpool vir die bedreiging in die persoon van die dwase of vreemde vrou. Wysheid se vroulikheid is bloot ' $n$ instrument om getrouheid aan Jahwe te herbevestig.

\section{Wysheid as gasvrou}

In Spreuke 9:1-6 rig die vrou Wysheid 'n uitnodiging aan die jongmanne om vir 'n maaltyd na haar huis toe te kom. Die beskrywing van die huis simboliseer haar gesag en outoriteit. Diegene wat haar feesmaal bywoon, erken haar gesag, en verlustig hulle in haar dinamiese geselskap (Clifford 1999:103). Dít staan in skerp kontras met die vrou Dwaasheid in Spreuke 9:13-18. Die ruimte waarin Dwaasheid optree en háár maaltyd aanbied, is niks meer nie as 'n stoel op 'n openbare plek in die stad. Die binnekant van haar huis word glad nie genoem of beskryf nie. Haar maaltyd is as't ware ' $n$ 'wegneemete', terwy die huis van die vrou Wysheid waardigheid, blywendheid en gehalte uitstraal.

Die beskrywing van die voedsel op die tafel beklemtoon die belang daarvan om die gawes van Wysheid te internaliseer. Die skrywer gebruik die potensieel erotiese ondertone en verwagtinge inherent aan so ' $n$ ete-uitnodiging by ' $n$ vrou se huis. Die maaltydtoneel is een van die min voorstellinge van die vrou Wysheid in ' $n$ sensuele atmosfeer, met die belofte van lyflike genot. Uit Spreuke 9:6 word dit egter gou duidelik dat hier nie van seksuele genot sprake is nie, maar dat die feesmaal bloot 'n geleentheid sal wees om insig te bekom. Boonop word dit as die voedsel vir die lewe beskryf. Soos vantevore bied Wysheid gawes en waardes wat tot die hoër funksies van die liggaam behoort - dinge wat in die manlike wêreld as waardevol en waardig geag is. Seksuele omgang met haar, dalk verbloemd aangebied om die jongmanne tot ' $n$ punt te verlei waar hulle ontvanklik is vir haar aanbod, is nie die doel nie. Baumann (1998:71) wys op die uiteindelike transendensie van Wysheid as vroulike skepping of uiting van God: 'People are to love the Wisdom Figure like a "personal goddess" and walk in her ways.' Wanneer die huis van die vrou Wysheid betree word, word dit gou duidelik dat ' $\mathrm{n}$ verhouding met haar ' $\mathrm{n}$ 'spiritual relationship of individuals towards her' (Baumann 1998:71) behels. Daardie verhouding is om vas te gryp - nie aan Wysheid se aanloklike lyf nie, maar aan die Godskonstruk van die patriargie: Jahwe self, die Heilige, soos uit Spreuke 9:10 blyk.

\section{Die Heilige is die spil waarom alles draai}

Spreuke 9:7-12 skyn die gedagtegang en tema van die kontrastering van die vrou Wysheid en die vrou Dwaasheid te onderbreek. Spreuke 9:10 dien as kulminasie van die gedagtegang van Spreuke 8:1-9:18, maar die omliggende gedagtes in Spreuke 9:7-9 en 11-12 is moeiliker integreerbaar by die tema in sy geheel.
Verskeie outeurs sien Spreuke 9:7-12 as redaksionele invoegings (Viviers 2005:885). Met die uitsondering van Spreuke 9:11, wat inhoudelik by Spreuke 9:1-6 aansluit (kyk Clifford 1999:106), blyk die gedeelte tóg die tema, bepaald dié van Spreuke 9:1-18, naamlik die teenstelling tussen wysheid en dwaasheid, aan te vul. Dít geskied deur middel van die personifikasie van die vrou Wysheid en die vrou Dwaasheid. Die doel is om die jongmanne van Israel tot volledige aanvaarding van Wysheid te oorreed. Dus word daar onder die mans self ook tussen wyses en dwases onderskei, en wel deur die terme 'wyse' en 'regverdige' aan die een kant, en 'ligsinnige' en 'goddelose' aan die ander kant. Dié invoegings verskerp die kontras, en beklemtoon in besonder die risiko en blywendheid van 'n verkeerde keuse tussen die twee. Die spil waarom hierdie kontrastering draai, is Spreuke 9:10: 'Wysheid begin met die dien van die Here; wie die Heilige ken, het werklik insig.' Jahwe se toetrede aan die een kant van dié kontras ken 'n genderbepaaldheid aan regverdigheid en wysheid toe, en koppel dus 'n manlike gender aan die vrou Wysheid. Haar vroulikheid word as lokmeganisme ontbloot; haar wese as die eienskappe van Israel se manlike God.

McKinlay (1996:67) beskryf Spreuke 9:7-12 as 'a dyptich, or mirrored poem, interrupted by units arranged chiastically, with the Yahwistic wisdom concept of v. 10 at its centre'. Die uitwerking van hierdie rangskikking, sowel struktureel as tematies, is dat dit Wysheid as't ware onder Jahwe se beheer bring, en haar magte ondergeskik stel aan God. Weereens is die verwantskap tussen Jahwe en Wysheid in veelduidige uitdrukkings en struktuur vasgelê, want veral in Spreuke 9:10 word die vrou Wysheid se status aan die een kant uitgelig, maar word sy terselfdertyd ondergeskik gestel aan Jahwe (se Heiligheid). Daar kan geen twyfel meer bestaan oor die aard van Wysheid, en oor die ware betekenis van 'insig' nie. 'n Onafhanklike, vroulike Wysheid regeer nie oor die lewe nie, maar is bloot ' $n$ metaforiese verwysing na Jahwe, en maak deel uit van die 'vrees' of 'dien' van die Here.

Malul (2002:220) vestig bepaald die aandag op die uitdrukking 'kennis van die Here', soos dit ook voorkom in Spreuke 9:10:

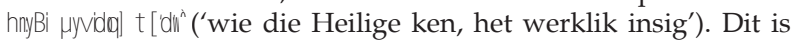
veral van belang en insiggewend as 'kennis' saam met hnki]; ('wysheid') gebruik word, soos in die volgende uitdrukking in dieselfde vers: humàtarknkx]; tLI T] ('Wysheid begin met die dien van die Here'). In die Bybelse wêreldbeeld of -visie was die volk se gebruike, tradisies, oorlewerings en kulturele konstrukte waaroor wysheid in wese gegaan het. Vir 'n gemeenskap om doeltreffend te kon funksioneer en te bly voortbestaan, moes die lede van daardie gemeenskap die reëls van die tradisie streng nakom, en die wette van oorlewering en verwantskap gehoorsaam. In die patriargale samelewing van Israel is die samelewing as 'n mikrokosmos van die makrokosmos beskou. Die makrokosmos is op die ideale liggaamskonstruk, hulle God, gemodelleer, wat ' $n$ manlike liggaamskonstruk was. Om goeie, wyse, opregte en regverdige mense te wees, moes die liggame van die Israelitiese mans dus aan die ideale van manlikheid voldoen. As wysheid begin met die dien van die Here, wil die vrou Wysheid hê dat daar uit die totaliteit van die kennis van God, soos oorgelewer en oorvertel en oorgeleef, geput moet word; om insig te hê, beteken om te weet wat dit is om te leef, of anders gestel, wat dit is om ' $\mathrm{n}$ man te wees. Wysheid is die pad of toegang na God se wil, en bied 'n blik op God: '[T]hose who know "he" know and respect the order, structure and workings of their "man's world" ' (Viviers 2005:885).

\section{Die vrou Dwaasheid se verleiding}

Die liggaamlikheid van die dwase vrou wat in Spreuke 9:13-18 beskryf word, staan voorop. Viviers (2005:886) wys daarop dat waar hierdie vrou ook al verskyn, erotiese temas aan die orde is. Die onderste gedeelte van die liggaam kom in fokus. Sy word op verskeie maniere as seksueel losbandig en verleidelik uitgebeeld. Die 'gesteelde water' wat sy in vers 17 aanbied, verwys waarskynlik na owerspel. In Spreuke 5:15-17 word 'water' as direkte verwysing na vroulike seksualiteit, dié van 'n 
vrou of eggenote, gebruik. Die 'kos wat stilletjies geëet word' dui op die ontmoeting tussen die vrou en die jongman wat in hoofstuk 7 beskryf word; die 'opwinding' van ' $\mathrm{n}$ verhouding terwyl die man weg van die huis af is.

Hierdie vrou is duidelik anders as die vrou Wysheid, wat met waardigheid, insig, dissipline en openlikheid optree. Haar 'andersheid' word nie daardeur bepaal dat sy tot 'n vreemde volk behoort nie, maar wel deur haar gender. Sy is ' $n$ losbandige vrou, wat nie soos 'n tipiese Israelitiese vrou optree nie, maar buite die familiestruktuur staan. Sy ondermyn die patriargale beheer van die familie, eiendom en die gemeenskap. Sy is nie 'n prostituut nie, maar doen haar so voor. Sy aap die vrou Wysheid na deur haar slagoffers met mooi woorde te verlei. Die eksplisiete seksualiteit van haar optrede toon haar as ' $\mathrm{n}$ gevaarlike, onbeheerbare mag wat vrees by die onskuldige jongmanne behoort in te boesem. Met haar liggaam lok sy uit, en haar doelwit is om te vernietig. Deur aan haar toe te gee, is om die dood self tegemoet te loop.

Waar die vrou Wysheid met eienskappe soos insig, waarheid en wysheid - alles 'geestelike' dinge - die hoër funksies van menswees verteenwoordig, is die dwase of vreemde vrou suiwer 'liggaam' - haar vroulike liggaamlikheid versinnebeeld chaos.

Seks is die merkteken dat iemand tot ' $n$ bepaalde groep behoort. Seksuele omgang of losbandigheid buite familieverband lei daartoe dat iemand buite die struktuur beland het en as't ware 'n barbaar word. In die geval van die seksuele verleiding deur die vrou in Spreuke 9:13-18 is die gevaar waaraan die jongman blootgestel word ' $n$ ruimtelike een: om sy plek in die struktuur te verloor. Voorts wys Malul (2002:301) daarop dat die seksdaad 'n soort omskrewe seremoniese rol vervul het waarmee ' $n$ onervare jongeling van die oorgangsfase tot die deelwordingsfase beweeg, met ander woorde, waar hy eers ' $n$ ongemerkte, ongedifferensieerde, onbekende en liggaamlik oningewyde entiteit was, verkry hy deur seks volle status, definisie en merktekens as deel van die struktuur. Seks is veronderstel om ' $n$ soort beskawingsmeganisme te wees. Die potensïele seksuele omgang met die losbandige, vreemde vrou hou die bedreiging in dat die jongman wél deel word van 'n struktuur, maar nie die struktuur van die Jahwe-gemeenskap waar hy ' $n$ verwekkingsrol kan vervul nie, maar wel in die antistruktuur, wat treffend in Spreuke 9:18 as die doderyk self beskryf word. Deur jou epistemiese apparaat te gebruik, maak jy aanspraak op toegang tot die sosiale struktuur. Die vrou Wysheid roep die jongmanne op om hulle epistemiese apparaat van gehoor, proe en gevoel te gebruik om deel van die Jahwe-gemeenskap en uiteindelik deel van Jahwe self te word. Die vreemde of dwase vrou nooi egter die jongmanne eksplisiet om ander epistemiese apparaat, hulle seksuele organe, te gebruik om haar te leer ken. Malul (2002:310) wys daarop dat die seksorgane en seksuele aktiwiteit as volledig deel van die mens se sintuiglike apparaat en werkinge beskou moet word. Net soos die wêreld deur die oë en ore beleef word, word dit eweneens deur die seksorgane beleef. Dié organe kan dus beskou word as ' $n$ epistemologiese instrument wat aan die mensdom gegee is om die wêreld mee te ervaar. Die seksdaad geskied dus as't ware as deel van die tassintuiglike. Dit hou ' $n$ sin van beheer en kennis in. Seksuele omgang kan dus as die ekwivalent van die 'vashou' of 'vasgryp' van iets beskou word. Van besondere belang vir ' $n$ begrip van die gevaar wat die dwase vrou inhou, is wat Malul (2002:310) as die 'wederkerigheid' van hierdie konnotasies beskryf. Sowel die man as die vrou beleef kennis, of oefen beheer uit, deur die seksdaad, waar die seksorgane die funksie van sintuiglike organe vervul. Die jongmanne van Israel loop dus gevaar om onder die beheer van die vrou Dwaasheid te kom, omdat sy (aangesien sý in hierdie geval die inisiatief neem) húlle wil leer ken. Jahwe wil ook leer ken word, maar via die sintuiglike organe waarop die vrou Wysheid aanspraak maak.

Om met die vreemde of dwase vrou seks te hê, sou beteken dat 'n man hom in die onbekende, die antistruktuur, die chaotiese, begeef. Die jongman stel sy lewe in gevaar, omdat hy nie slegs hierdie gevaarlike, chaotiese magte sal leer ken nie, maar daardeur geken, beheer en uiteindelik vernietig sal word. Aan die ander kant sou 'omgang' met die vrou Wysheid (deur die organe waarop sy aanspraak maak, wat vanweë haar eenwees met Jahwe nie eksplisiet die seksorgane insluit nie) tot ' $n$ gebalanseerde, gesonde en heel liggaam, die perfekte manlike liggaam, lei. Om die vrou Wysheid te leer ken en te internaliseer, lei tot die lewe, want die lewe is balans. Om die vrou Dwaasheid in te neem en in te laat, hou die gevaar in dat jy soos sy kan word, naamlik onbeheersd en ongebalanseerd, en in besonder, om jou plek in die gemeenskap (wat deur regop, gesonde, manlike liggame verpersoonlik word) te verloor.

Die vrou Wysheid is ' $n$ kontrapersoon. In diens van Jahwe se manlikheid, staan sy die gevare vir die mans van Israel, soos beliggaam in die persoon van die vreemde of dwase vrou, teen. Albei figure - sowel die vrou Wysheid as die vrou Dwaasheid - bepaal en verseker die grense van die simboliese orde van patriargale wysheid (Maier 1998:106). Die beeld van 'n jong Israelitiese man wat naïef, swakwillig en onbeheersd is, is ondraaglik. Niemand wil soos die vrou Dwaasheid wees nie. Die vrou Wysheid bied die regte weg na die regte liggaam, naamlik Jahwe.

\section{Gendertweeledigheid}

Wat die liggaamsideologie onderliggend aan die Godskonstruk betref, dien vroulikheid en manlikheid in Spreuke 8 en 9 as teenpole. Dat die vrou Wysheid te midde van daardie teenstellendheid kon intree, laat wél die deur vir verdere nadenke oor God oop. Dít sou egter beteken dat die vrou Dwaasheid, só eksplisiet vroulik, met ' $\mathrm{n}$ sagter oog bekyk moet word. Solank die vreemde vrou, in Baumann (1998:107) se woorde, die ou patriargale cliché van vroue as 'seksueel onbeheersd en afwykend' weerspieël, is daar egter nie veel hoop om in ' $n$ Godskonstruk ook vir vroulikheid ruimte te vind nie.

\section{EKOTEOLOGIESE IMPLIKASIES}

'n Liggaamsideologie waarin daar in die daarstel van ' $n$ Godskonstruk ook vir vroue ruimte is, sal tot die uitbou van die waarde van ekobillikheid bydra. Daarom word die liggaamsideologie onderliggend aan Spreuke 8 en 9 vervolgens aan die hand van die ses ekobillikheidsbeginsels van die Earth Bible-projek (Habel 2000) bespreek.

\section{Intrinsieke waarde}

Die beskrywing van die skepping in Spreuke 8:22-31 stel dit nie ten doel om die intrinsieke waarde van die Aarde en haar bewoners weer te gee nie. Die kosmos dien eerder as die agtergrond waarteen die oorsprong van die vrou Wysheid beskryf en haar verhouding met Jahwe geregverdig word. Voorts is die beskrywing van die geskape wêreld heel oppervlakkig: Daar is byvoorbeeld geen sprake van lewende wesens (buiten mense) of plante nie. Tog blyk daar in die beperkte beskrywing 'n mate van diversiteit, ' $n$ implisiete waardetoekenning, te wees, al is dit bloot ' $n$ verskeidenheid van geologiese verskynsels. Die vrou Wysheid sê in Spreuke 8:31: 'Ek het my verlustig in die wêreld wat Hy gemaak het...'. Groot waters en fonteine, berge, rante en vlaktes, die grond, die hemelgewelf en die horison, die see en die wolke, die fondamente van die aarde - daar is wél ruimte om jou soos die vrou Wysheid aan die geologiese aardse verskynsels te verwonder. Die metafore wat gebruik word om die kosbaarheid van die eienskappe van Wysheid aan te dui, kom ook uit die grond: silwer, goud en edelstene. Hulle waarde staan weliswaar, soos die vrou Wysheid, in diens van die manlike Godskonstruk van Israel. Voorts het die mens dit deur verfyningsprosesse as kultuurprodukte aangewend. Die Aarde en haar berge, dale en minerale staan dus waarskynlik ondergeskik aan God en die mens. Tog wys die vrou Wysheid in 'n mate die regte weg aan: 'Woman Wisdom is not only involved in creating Earth and Earth community; she also continues to revel in their mysteries and wonders." (Habel 2001b:29) 


\section{Onderlinge verbondenheid}

Die beginsel van onderlinge verbondenheid behels onder andere ' $n$ wedersydse afhanklikheid tussen die Aarde en haar skepsele. Spreuke 8 en 9 ken ' $n$ tipiese bemiddelingsrol aan die vrou Wysheid toe. Haar bemiddeling is egter tussen die mans van Israel, en Jahwe. Aarde en see, wolke en vlaktes, word as die handewerk van Jahwe beskryf. As daar van afhanklikheid sprake is, is dit hiërargies van aard, in dié sin dat soos die Aarde en haar skepsele in Genesis 1 'n mikrokosmos van die ideale Godskonstruk uitmaak, die jongmanne se liggame op dié van Jahwe gemodelleer word.

Die transendente vrou Wysheid is die enigste lewegewende entiteit (as verpersoonliking van Jahwe) in Spreuke 8 en 9. Hobgood-Oster (2001:40) beskryf haar as 'n manier om die hiërargiese struktuur uit te daag. Die goddelike wese wat haar in die skepping van die wêreld verlustig, vertoon 'n algeheel ander beeld as die een van 'n koning wat op die troon sit met die aarde as sy voetstoel. Of die loflied op die vrou Wysheid se lippe egter méér simboliseer as net 'n versterking van 'n hiërargiese skeppingsteologie, waar die manlike Jahwe die hoogste troon beklee, is te betwyfel. Daar is nie veel sprake van ' $n$ viering van die totstandkoming van die skeppingsentiteite nie.

\section{Stem}

Die vrou Wysheid roep, skree en praat baie; die vrou Dwaasheid fluister en raas tegelyk; Jahwe (het) beveel. Die Aarde is stil, of is sy? Wurst (2001:49-59) doen aan die hand dat die stem van die vrou Wysheid, Jahwe se vertroueling en medeskepper van die aarde en aardse gemeenskap, die stem van die Aarde en haar bewoners verteenwoordig. Die vrou Wysheid koppel haar rol nie net aan bepaalde optredes nie, maar in besonder aan kennis en insig. Haar bestaanswyse word deur die term 'ekoverwantskap' beskryf. Vanweë haar kennis van die skepping, tree sy as bemiddelaar op tussen die aarde en almal wat wil luister. As die wyse stem van die vrou Aarde, onderrig sy die jongmanne, trouens alle mense, in die geheimenisse van die skepping.

Daarenteen is die welluidendheid van die stem van die vrou Wysheid vir Hobgood-Oster (2001:36) opmerklik: 'Woman Wisdom/Sophia's feminine voice shouts from the marketplace to all who can hear, instructing us to give up our foolish ways...'. Tog bestempel Hobgood-Oster die aard van die wysheidsboeke as die toppunt van patriargale heerskappy.

Dié navorser meen die stem van die vrou Wysheid het 'n enkele boodskap, naamlik om die inherente waardes van Jahwe, die Heilige, by die mans van die gemeenskap te vestig om voortgang en stabiliteit te bewerkstellig. Daarteenoor verkondig die stem van die vrou Dwaasheid verleidelikhede wat tot die mans se dood sal lei. Indien wysheid beteken om die Aarde en haar skepsele as ondergeskik aan die bevele van die Israelitiese Godskonstruk te beskou, wat onder andere die mens die opdrag gegee het om oor alles te heers en dit te domineer, dan is die stem van die vrou Wysheid nie die stem van die vrou Aarde wat om billikheid, deernis en die verantwoordelikheid van onderlinge versorging roep nie. Dit is ironies dat indien die stem van die vrou Dwaasheid help om die aarde se menslike bevolking in toom te hou deur die jongmanne op 'n vroeë leeftyd in die doderyk te laat beland, háár stem eerder by die huidige noodroep van die oorbevolkte vrou Aarde sou aansluiting vind.

\section{Doel}

Die aarde, see, berge en vlaktes as skeppingswerke bevestig die oorsprong van die vrou Wysheid, en maak dus die lewe vir haar moontlik. Tog word die oorsprong van die lewe, minstens vir die jongmanne van Israel, in Spreuke 9:6 en Spreuke 9:11 as die wysheid bestempel wat die vrou met die kennis- en insigbestanddele van haar maaltyd aanbied. As die kosmologiese terminologie enige verwysing na 'n ontwerp met lewegewende rigting behels, word dit agter die verlustiginge van die vrou Wysheid verberg. Die vrou Dwaasheid het geen plek in hierdie oorhoofse doel nie. Sy behoort tot die onderwêreld, waarheen sy ook Israel se mans lok.

Hobgood-Oster (2001:41-42) hoor in Spreuke 8:30-31 hoe die vrou Wysheid die aarde as 'n wonderwerk, 'n voorwerp van verwondering, bestempel. Daaruit lei sy af dat intieme en passievolle kennis van die aarde, en dus die oorhoofse ontwerp en dinamiese doel van alle skeppingswerke, wysheid verteenwoordig. Daarteenoor stel Spreuke 9:10 die beginsel van wysheid anders. Wysheid begin met die dien van Jahwe, en kennis van die Heilige (die Godskonstruk) van Israel.

\section{Gemeenskaplike sorg}

Hierdie beginsel van ekobillikheid behels die afwesigheid van dominerende, hiërargiese strukture, en 'n onderlinge vennootskap tussen alle skepsele in die kosmos. In Spreuke 8 en 9 is die klas- en gendervooroordele egter duidelik en eksplisiet. Tóg is die stem van die vrou Wysheid eweneens duidelik en eksplisiet. Hobgood-Oster (2001:46) bepleit 'n herkontekstualisering van die vrou Wysheid se boodskap, veral wat die bemagtiging van heersers betref. Om koning te wees, behels die verkryging van mag. Sy stel voor dat die vrou Wysheid se woorde oor en aan heersers as 'n dekonstruksie van die sosiale, politieke en godsdienstige magstrukture vertolk word. Jahwe en die vrou Wysheid, wat die aarde goed ken en hulle in die aarde se oorvloed verlustig, ondermyn die patriargie en androsentrisme, en wys 'n nuwe pad na wysheid aan.

Dit blyk egter uit die ontleding hier bo dat die vrou Wysheid in die eerste plek die bemagtiging van Israel se mans wat betref hulle verhouding in die kultus, hulle verhouding teenoor Jahwe, en hulle verhouding met mag, eer en rykdom ten doel het. Jahwe sorg heel eerste vir die mans van Israel. Die vrou Wysheid en Jahwe was dalk vennote in die skeppingsproses (en selfs dáárdie vennootskap word deur die uitbeelding van die vrou Wysheid se geboorte in Spreuke 8:22-25 ondermyn), maar van 'n vennootskap tussen mans en vroue en ander skepsele is daar geen sprake nie.

\section{Weerstand}

Ál weerstand waarvan daar in Spreuke 8 en 9 sprake is, is dié van die ligsinniges, die dwases en oningeligtes wat nie vir die aanbod van die vrou Wysheid val nie. Die see waarvoor Jahwe grense moet stel en bevele uitvaardig, hou moontlik 'n mate van weerstand in. Weens die genderpolarisasie in die persone van die twee vroue, is sowel die ligsinniges as die see egter chaoties en onbeheersd eerder as beheersd weerstandig, en begerig om te herleef en te laat herleef. Die kosmologie van Spreuke 8 en 9 dra nie by tot die vestiging van lewegewende weerstand as inherente eienskap of beginsel van die lewe op en deur die aarde nie.

Daar is wél potensiaal in die geboortemetafoor waarvolgens die vrou Wysheid tot stand gekom het. Dit sal egter drastiese herkontekstualisasie verg om in die Spreukeboek die aarde in 'n aktiewe rol van weerstand en geboorteskenking te skets.

Miskien is die naaste wat Spreuke 8 en 9 dus aan ekobillikheid kom, soos Cox (1982:156) dit stel, die waarde van die kommunikasiegebeure soos dit deur die vrou Wysheid verpersoonlik word:

Through her, God's act of creation becomes an act of communication: as God goes outside of himself so as to meet mankind on a mutually appreciable level. There he, like Wisdom herself, can "delight in the sons of men."

(Cox 1982:156)

\section{LITERATUURVERWYSINGS}

Baumann, G., 1998, 'A figure with many facets: The literary and theological functions of personified wisdom in Proverbs 1-9', in A. Brenner \& C. Fontaine (reds.), Wisdom and Psalms: A feminist companion to the Bible, pp. 44-78, Sheffield Academic Press, Sheffield. 
Clifford, R.J., 1999, Proverbs: A commentary, Westminster John Knox, Louisville.

Cox, D., 1982, Proverbs with an introduction to the Sapiental Books, Michael Glazier, Wilmington.

Eilberg-Schwartz, H., 1995a, 'Introduction: The spectacle of the female head', in H. Eilberg-Schwartz \& W. Doniger (reds.), Off with her head: The denial of women's identity in myth, religion, and culture, pp. 1-13, University of California Press, Berkeley.

Eilberg-Schwartz, H., 1995b, 'The nakedness of a woman's voice, the pleasure in a man's mouth: An oral history of Ancient Judaism', in H. Eilberg-Schwartz \& W. Doniger (reds.), Off with her head: The denial of women's identity in myth, religion, and culture, pp. 165-184, University of California Press, Berkeley.

Fontaine, C.R., 2002, Smooth words: Women, Proverbs and performance in biblical wisdom, Sheffield Academic Press, Sheffield.

Fox, M.V., 2000, Proverbs 1-9: A new translation with introduction and commentary, Doubleday, New York.

Habel, N. (red.), 2000, Introducing the Earth Bible: Readings from the perspective of Earth, The Earth Bible 1, Sheffield Academic Press, Sheffield.

Habel, N. (red.), 2001, Where is the Voice of Earth in Wisdom Literature?, in N.C Habel \& S. Wurst (reds.), The Earth Story in Wisdom Traditions, The Earth Bible 3, pp. 13-34, Sheffield Academic Press, Sheffield.

Hobgood-Oster, L., 2001, 'Wisdom literature and ecofeminism', in N.C. Habel \& S. Wurst (reds.), The Earth story in wisdom traditions, The Earth Bible 3, pp. 35-47, Sheffield Academic Press, Sheffield.
Leder, D., 1990, The absent body, The University of Chicago Press, Chicago.

Maier, C., 1998, 'Conflicting attractions: Parental wisdom and the 'strange woman' in Proverbs 1-9', in A. Brenner \& C. Fontaine (reds.), Wisdom and Psalms: A feminist companion to the Bible, pp. 92-109, Sheffield Academic Press, Sheffield.

Malul, M., 2002, Knowledge, control and sex. Studies in biblical thought, culture and worldview, Archaelogical Center Publication, Tel Aviv.

McKinlay, J.E., 1996, 'Gendering Wisdom the host: Biblical Invitations to Eat and Drink', Journal for the Study of the Old Testament, suppl. ser. 216.

Murphy, R.E., 1998a, 'Wisdom and Creation', in A. Brenner, \& C. Fontaine (reds.), Wisdom and Psalms: A feminist companion to the Bible, pp. 32-42, Sheffield Academic Press, Sheffield.

Murphy, R.E., 1998b, Proverbs, World biblical commentary 22, Thomas Nelson, Nashville.

Pentiuc, E.J., 2001, 'A self-offering God and his begotten wisdom (Proverbs 8:22-24)', Greek Orthodox Theological Review 46, 255265.

Viviers, H., 2005, 'The ody and Lady Wisdom (Proverbs 1-9)', Old Testament Essays 18(3), 879890.

Vorster, J.N., 2002, 'The blood of female martyrs as the sperm of the early church', Religion and Theology 9, 8-41.

Wurst, S., 2001, 'Woman Wisdom's Way: Ecokinship, in N.C. Habel \& S. Wurst (reds.), The Earth story in wisdom traditions, The Earth Bible 3, pp. 48-64, Sheffield Academic Press, Sheffield. 